\title{
SEROPREVALANCE OF Toxoplasma gondii INFECTION AMONG PSYCHIATRIC DISEASES ${ }^{(1)}$
}

\section{PSIIKIYYATRİK HASTALARDA Toxoplasma gondii SEROPREVALANSI}

\author{
Necati OZPINAR', Tugba KAYA', Zekeriya YELBOGA ${ }^{3}$, Nuryil YILMAZ4, \\ Semra OZCELIK \\ ${ }^{1}$ Hatay Mustafa Kemal University, Faculty of Health Science, Antakya / Turkey \\ ${ }^{2}$ Hatay Mustafa Kemal University, Faculty of Medicine, , Antakya / Turkey \\ ${ }^{3}$ Cumhuriyet University School of Medicine, Department of Psychiatry, Sivas / Turkey \\ ${ }^{4}$ Cumhuriyet University School of Medicine, Department of Psychiatry, Sivas / Turkey \\ ${ }^{5}$ Bezmialem Vakif University, Health Sciences Institute, Istanbul / Turkey
}
ORCID ID: 0000-0002-7317-885X $X^{1}, 0001-7612-5414^{2}, 0000-0001-7880-2247^{3}$, 0000-0002-6229-91974, 0000-0001-9237-67235

\begin{abstract}
Öz: Amaç: Bu çalışmada psikiyatrik hasta gruplarında Toxoplasma gondii seroprevalansının araştırılması amaçlandı. Metot: Sivas Cumhuriyet Üniversitesi Sağlı Uygulama ve Araştırma Hastanesi psikiyatri polikliniğine başvuran hasta gruplarında Toxoplasma gondii seroprevalansının belirlenmesi için, ELISA yöntemi ile anti-Toxoplasma gondii-IgG ve anti-Toxoplasma gondii-IgM antikorlarının varlı̆̆ araştırıldı. Çalışmada 18-80 yaş arası, 175 psikiyatrik hasta (65 şizofreni hastası, 46 Depresyon ve 64 Bipolar Affektif Bozukluk(BAD)) ve aynı yaş grubundaki 100 sağlıklı bireyler kontrol grubu olarak belirlendi. Bulgular: Toxoplasma gondii IgG antikorları 65 şizofreni hastasının 33 'ünde (\% 50.76), 46 depresyon hastasının 24 'ünde (\% 52.17) ve 64 BAD hastasinin 30 'unda (\% 46.87) pozitif bulundu. Bu oran kontrol grubunda $25(\% 25)$ olarak belirlendi. Toxoplasma gondii IgM antikorları şizofreni tanılı 65 hastanın 4 'ünde $(\% 6.15)$ ve BAD hastalarının 5 'inde (\% 7.81) bulundu. 46 depresyon hastasinda toksoplazma IgM antikorları bulunmad. Bu oran kontrol grubunda $1(\%)$ ) olarak belirlendi. Sonuç: Şizofreni ve bipolar bozukluğu olan hastalarda Toxoplasma gondii enfeksiyonu prevalansı kontrol grubuna göre anlamlı derecede yüksek bulundu. Psikiyatrik bozukluklarda anti-Toxoplasma gondii antikorlarının ölçümü, hastalığın değerlendirilmesine ve tedavinin zamanında başlatılmasına olanak tanımaktadır. Toxoplasma gondii enfeksiyonunun, psikiyatrik bozukluğu olan hastalarda risk faktörü oluşturabileceği sonucuna varılıış̧ır.

Anahtar Kelimeler: T. Gondii; Psikiyatrik Hastalıklar; ELISA
\end{abstract}




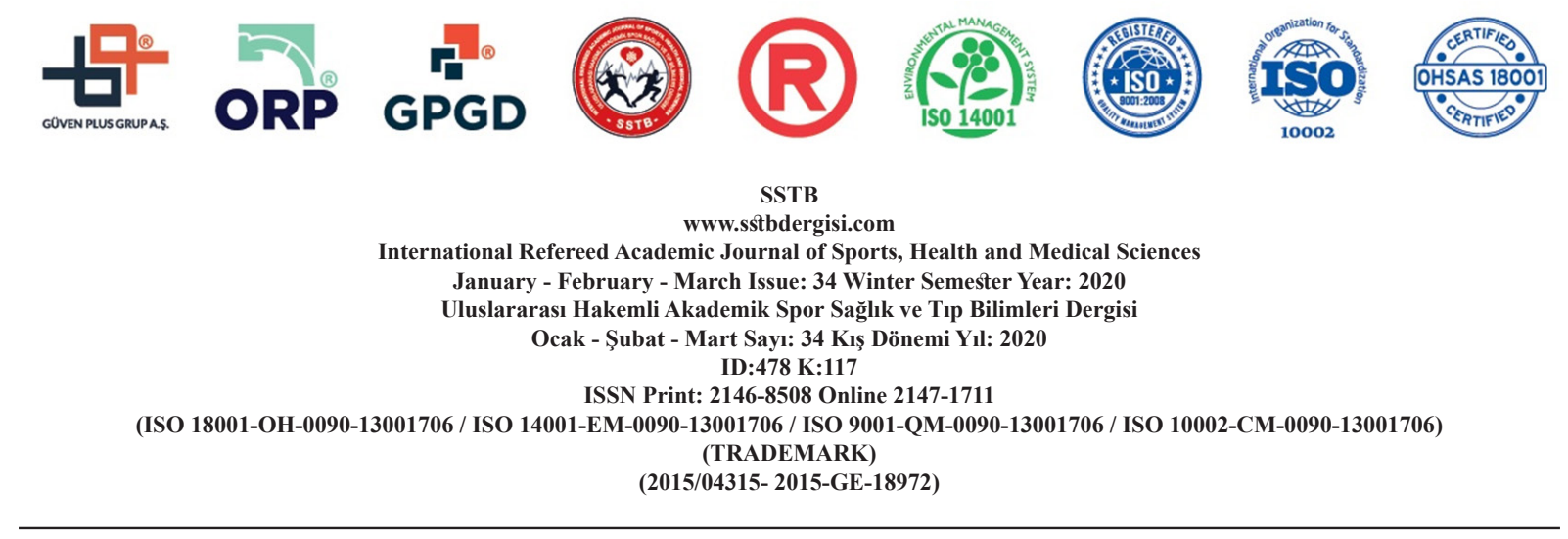

\section{INTRODUCTION}

The protozoan parasite Toxoplasma gondii ( $T$. gondii) is widely distributed throughout the world. It is in Phylum Apicomplexa, and its life cycle can only be completed in cats that are definitive hosts. However, T. gondii also infects a wide variety of intermediate hosts, including humans (Sharif et al., 2015:1-16). Latent toxoplasmosis, commonly seen in immunocompetent individuals, until recently was believed to be asymptomatic as a result of a balance between the immune system and the parasite (Walochnik et al., 2017:177189). In addition, various neurological symptoms, such as incoordination, head-shaking, tremors, and seizures, recently have been described in monkeys, sheep, pigs, cattle, rabbits infected with $T$. gondii (Torrey et al., 2003:1375).

Recent epidemiologic studies indicate that infectious agents may contribute to some cases of schizophrenia (Celik et al., 2015:015; Torrey et al, 2006:729-736; Yolken et al, 2017: e0006040). In animals, infection with $T$. gondii can change the behavior and neurotransmitter function. In humans, acute infection with $\mathrm{T}$. gondii may produce psychotic symptoms similar to those seen in schizophrenia patients (Torrey et al., 2003:1375).

Toxoplasma parasites have also been shown to impair learning and memory in mice and to produce behavioral changes in both mice and rats (Aiello et al., 1998:143-156). Of particular interest are studies showing that Toxoplasma-infected rats become less neophobic, leading to the diminution of their natural aversion to the odor of cats (Mandarino, 1992:1892-1901). These behavioral changes increase the chances that a cat will eat the rat, thus enabling Toxoplasma to complete its life cycle, an example of evolutionarily driven manipulation of host behavior by the parasite (Berdoy et al, 2000:1591-1594; Torrey, 2003:1375; Witting et al., 1979:29-51).

In Sivas, the second largest province in Turkey by territory, that located mainly at the eastern part of the Central Anatolia region of Turkey, there is no data about seropositive of T. gondii infection in patients suffering from psychiatric diseases, and there is no information about risk factors increasing the seroprevalence of T. gondii in patients with psychiatric diseases. The successful identification of blood-based antibody markers for latent infections including Toxoplasma would represent an advance in the prediction and prevention of psychiatric diseases and their complications in this population. After considering these thoughts about the relationship of $T$. gondii and psychiatric diseases, we thought that a study investigating the seroprevalence of $T$. gondii and psychiatric diseases could make a considerable contribution to the screening and diagnosis 


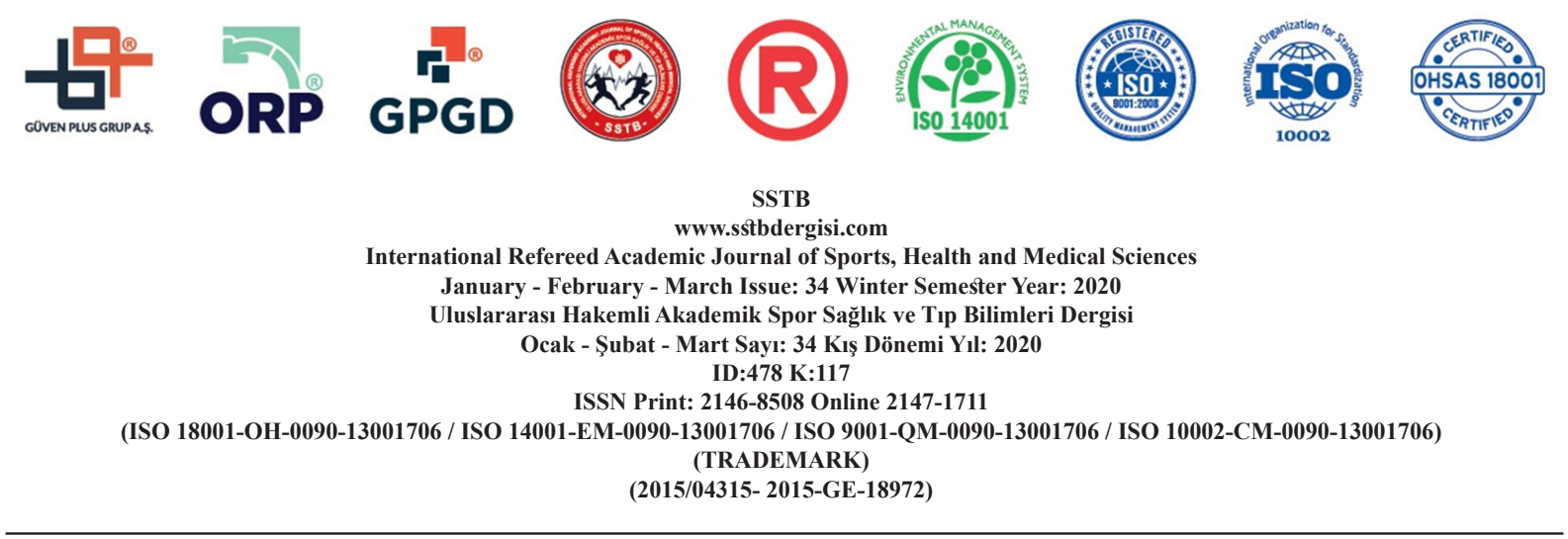

and follow-up of psychiatric disorders. The present study aimed to investigate the seroprevalence of Toxoplasma in clinically wellcharacterized samples of psychiatric patients.

\section{MATERIALS and METHODS}

\section{Methods}

This cross-sectional study was performed on psychiatric patients referred to Psychiatry outpatient clinic of Healthcare Application and Research Hospital. All patients who were referred to the psychiatry center and would like to contribute in our study were questioned about demographic characteristics, abortion, the habit of feeding cats and consumption of raw or undercooked meat. All patients and healthy individuals who gave written consent were recruited in this study using the convenience sampling method.

The study included the samples from 175 psychiatric patients (65 patients with schizophrenia, 46 Depression and 64 Bipolar Affective Disorder (BAD)) aged from 18-80 years old and samples from 100 the same age range healthy individuals as a control group. A blood sample of 2-3 $\mathrm{ml}$ was taken from patients aged. The blood sample was centrifuged at $1500 \mathrm{rpm}$ for 10 mins for separation of the serum. The serum samples were stored at $-20^{\circ} \mathrm{C}$ until assay. The Toxo-IgG and ToxoIgM antibodies were investigated in the test serums with the enzyme-linked immunosor- bent assay (ELISA) using Dia Pro (Milan, Italy) commercial kits with $100 \%$ sensitivity and $100 \%$ specificity. The ELISA was performed and evaluated according to the Dia Pro (Milan, Italy) kits procedure. Absorbance plate wells were read at a wavelength of 450 nm with a plate reader (Labomed EMR-500, USA).

\section{Statistical Analysis}

The row data was entered and analyzed by the SPSS v22.0 statistics program. In the evaluation of the data, as the parametric test assumptions were not met, Fisher's Exact test was used. A value of $p<0.05$ was accepted as statistically significant.

\section{RESULTS}

Serum samples collected from 175 psychiatric patients (65 patients with schizophrenia, 46 Depression and 64 BAD) were examined for $T$. gondii antibodies with the ELISA method. The results were compared with those of serum samples collected from 100 healthy individuals.

Toxoplasma IgG antibodies were found to be positive with the ELISA method in 87 (49.7\%) of the 175 psychiatric patients. This rate was determined as $25 \%$ in the control group. There was a significant difference between the groups $(\mathrm{p}<0.05)$. Toxoplasma IgG antibodies were found positive in $33(50.76 \%)$ of 
www.sstbdergisi.com

International Refereed Academic Journal of Sports, Health and Medical Sciences

January - February - March Issue: 34 Winter Semester Year: 2020

Uluslararası Hakemli Akademik Spor Sağlık ve Tıp Bilimleri Dergisi Ocak - Şubat - Mart Sayı: 34 Kıș Dönemi Yıl: 2020 ID:478 K:117

ISSN Print: 2146-8508 Online 2147-1711

(ISO 18001-OH-0090-13001706 / ISO 14001-EM-0090-13001706 / ISO 9001-QM-0090-13001706 / ISO 10002-CM-0090-13001706) (TRADEMARK)

(2015/04315- 2015-GE-18972)

65 schizophrenia patients, in $24(52.17 \%)$ of 46 depression patients and $30(46.87 \%)$ of 64

BAD patients. When the patient groups were compared with the control group, the difference was found to be statistically significant. $(\mathrm{p}<0.05$, Table 1, Figure 1).

Table 1. Distribution of the anti-Toxo IgG and IgM Positive Results of the Psychiatric Oisorders and Control Groups

\begin{tabular}{lllll}
\hline & $\begin{array}{l}\text { Controls } \\
(\mathrm{n}=100)\end{array}$ & $\begin{array}{l}\text { Schizophrenia } \\
(\mathrm{n}=65)\end{array}$ & $\begin{array}{l}\text { Depression } \\
(\mathrm{n}=46)\end{array}$ & $\begin{array}{l}\mathrm{BAD} \\
(\mathrm{n}=64)\end{array}$ \\
\hline $\operatorname{IgG}$ & $25(25 \%)$ & $33(50.76 \%)$ & $24(52.17 \%)$ & $30(46.87 \%)$ \\
\hline $\operatorname{IgM}$ & $1(1 \%)$ & $4(6.15 \%)$ & 0 & $5(7.81 \%)$ \\
\hline $\operatorname{IgG}+\operatorname{IgM}$ & 0 & $2(3.07 \%)$ & 0 & $3(4.68 \%)$ \\
\hline
\end{tabular}

Fisher's Exact, $\mathrm{p}=0.014, \mathrm{BAD}$ : Bipolar Affective Disorder

\section{anti-Toxo IgG results of psychiatric diseases and control group}

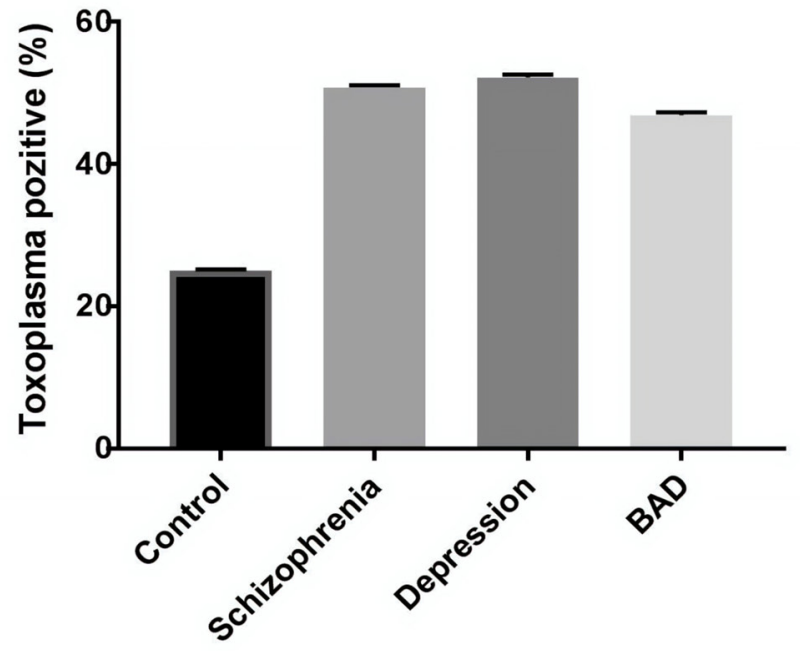

Control

Schizophrenia

Depression

BAD

\section{Psychiatric patient groups}

Figure 1. Anti-Toxo IgG Results of Psychiatric Diseases and Control Group (BAD: Bipolar Affective Disorder) 
International Refereed Academic Journal of Sports, Health and Medical Sciences

January - February - March Issue: 34 Winter Semester Year: 2020

Uluslararası Hakemli Akademik Spor Sağlık ve Tıp Bilimleri Dergisi

Ocak - Şubat - Mart Sayı: 34 Kış Dönemi Yıl: 2020 ID:478 K:117

ISSN Print: 2146-8508 Online 2147-1711

(ISO 18001-OH-0090-13001706 / ISO 14001-EM-0090-13001706 / ISO 9001-QM-0090-13001706 / ISO 10002-CM-0090-13001706) (TRADEMARK)

(2015/04315- 2015-GE-18972)

Toxoplasma $\operatorname{IgM}$ antibody positivity was determined in $10(5.7 \%)$ patients of the patient group and only 1 of the control group. There was a significant difference between the groups $(\mathrm{p}<0.05)$. Toxoplasma IgM antibodies were found in $4(6.15 \%)$ of 65 patients with schizophrenia and $5(7.81 \%)$ of BAD patients. Toxoplasma IgM antibodies were not found in 46 depression patients. When the patient groups were compared with the con- trol group, the difference between the patients with depression was insignificant, while the difference between schizophrenia and BAD patients was significant $(\mathrm{p}<0.05$, Table 1 , Figure 2). Also, Toxoplasma IgG antibodies and Toxoplasma IgM antibodies were found positive in 5 patients. Of these, 2 (3.07\%) had schizophrenia, and 3 (4.68\%) had BAD (Table 1).

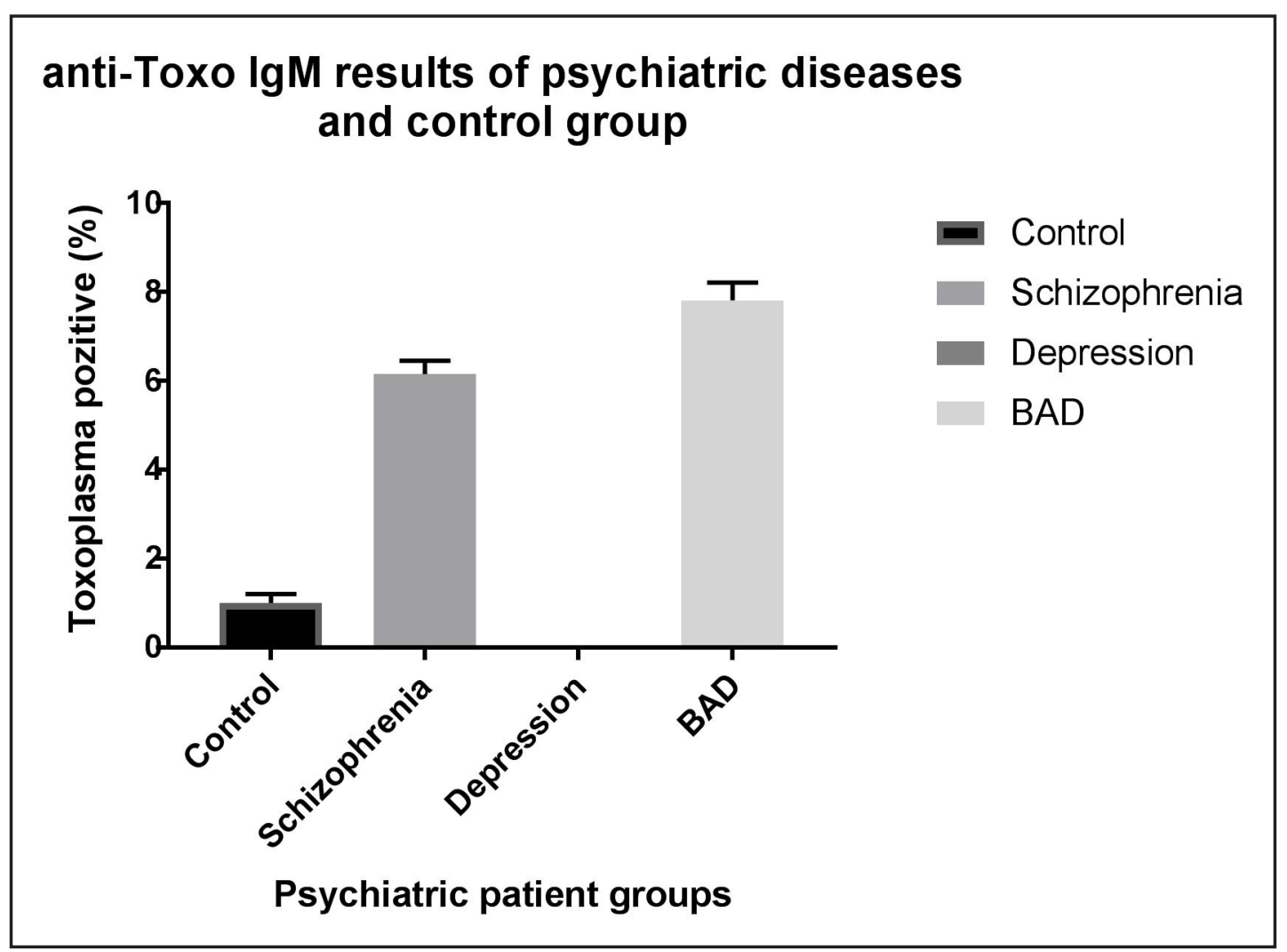

Figure 2. anti-Toxo IgM Results of Psychiatric Diseases and Control Group (BAD: Bipolar Affective Disorder) 


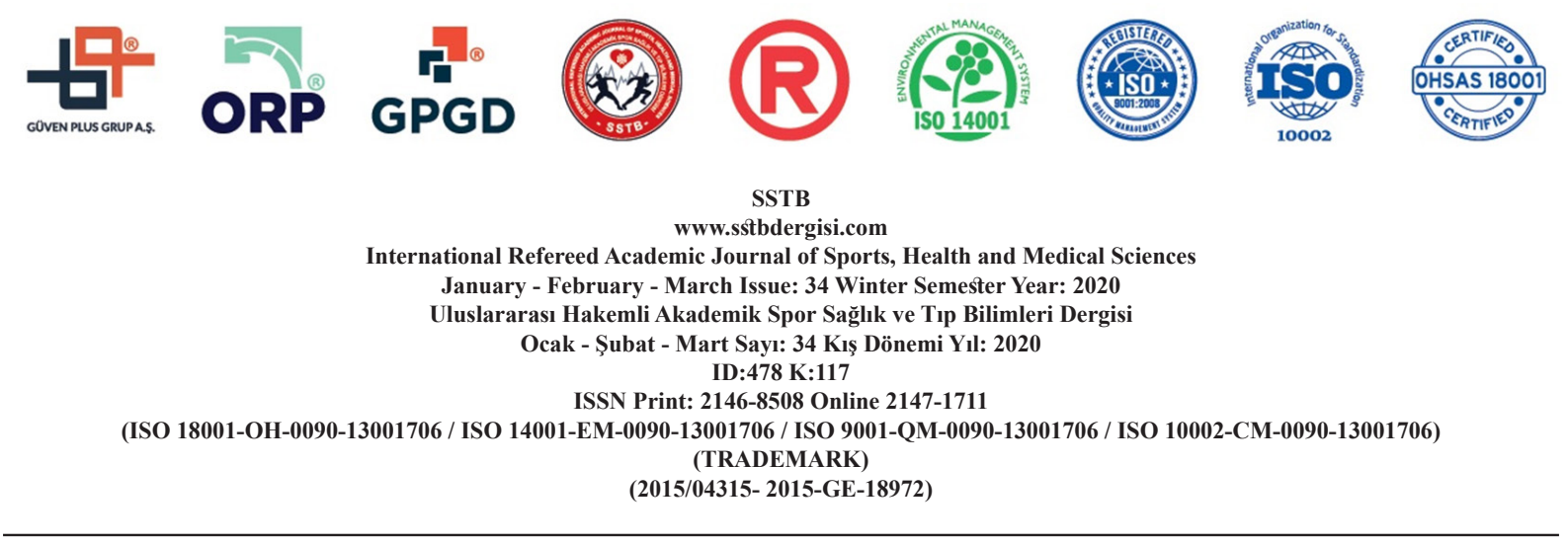

\section{DISCUSSION}

The seropositivity of toxoplasmosis varies between $5-90 \%$ worldwide. The prevalence of toxoplasmosis in our country is reported to vary between $12-65 \%$. (Boluk et al., 2012:137-141). It is known that toxoplasmosis is an important cause of abortion and stillbirths in many mammalian species and selectively infects muscle and brain tissue. It has been shown that Toxoplasma disrupts learning and memory in mice and causes behavioral changes in both mice and rats. Rats normally escape cat odor, but studies are showing that rats infected with Toxoplasma do not escape cat odor (Berdoy et al., 2000:1591-1594; Witting, 1979:29-51). Under normal conditions, mice and rats, which the intermediate host of the parasite, are expected to stay away from that area, by fearing the smell of cat urine. In their brains, infected rodents carrying the tissue cyst of the parasite have been observed to show a behavioral change in the direction of not being afraid of cats. This causes cats to hunt more easily. It has been shown that the natural and learned fear reactions against cat urine not only decreased in infected rodents but also perceived the smell as a pheromone and increased their interest in sex. These behavioral changes increase the likelihood that the mouse will be eaten by a cat, thus allowing Toxoplasma to complete its life cycle.
As in other intermediate hosts, Toxoplasma parasites in humans may also form tissue cysts in many organs, including the brain. It was previously thought that Toxoplasma did not cause any symptoms in the immune component host. However, recent studies have interaction Toxoplasma with many neuropsychiatric disorders such as schizophrenia (Torrey et al, 2003:1375, 2017:247-252), BAD (Hamdani et al., 2013:444-448), suicide behavior (Zhang et al., 2012:1069-1076), anxiety disorder (Markovitz et al., 2015:192-197).

In a study, a group of 2052 patients with 1481 psychiatric disorders and 571 healthy controls was formed, and the Toxoplasma relationship with psychiatric disorders was tested. As a result of this study, Toxoplasma prevalence was not found to have a significant prevalence in patients with psychiatric disorders other than schizophrenia and psychosis (Yolken et al., 2017: e0006040). In our study, 33 (50.76\%) of 65 schizophrenia patients, $24(52.17 \%)$ of 46 depression patients and $30(46.87 \%)$ of 64 BAD patients were positive for Toxoplasma IgG antibodies, and the difference was significant compared to control group composed of healthy individuals.

When Toxoplasma IgM seropositivity examined, was found to be positive for Toxoplasma IgM antibodies in $4(6.15 \%)$ of 65 schizophrenia patients and $5(7.81 \%)$ of 64 

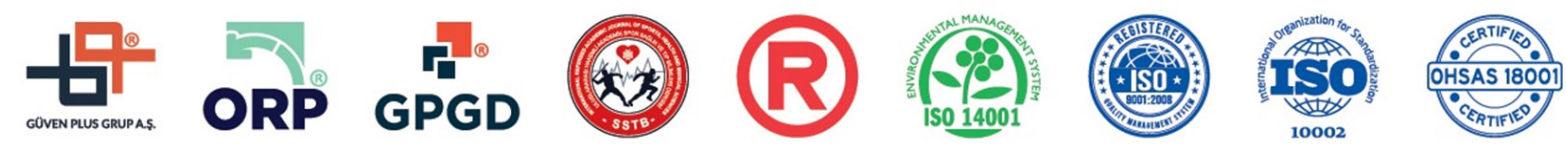

SSTB

www.sstbdergisi.com

International Refereed Academic Journal of Sports, Health and Medical Sciences

January - February - March Issue: 34 Winter Semester Year: 2020

Uluslararası Hakemli Akademik Spor Sağık ve Tıp Bilimleri Dergisi

Ocak - Şubat - Mart Sayı: 34 Kış Dönemi Yıl: 2020 ID:478 K:117

ISSN Print: 2146-8508 Online 2147-1711

(ISO 18001-OH-0090-13001706 / ISO 14001-EM-0090-13001706 / ISO 9001-QM-0090-13001706 / ISO 10002-CM-0090-13001706) (TRADEMARK)

(2015/04315- 2015-GE-18972)

BAD patients. Toxoplasma IgM antibodies were not found in 46 depression patients.

When the data were compared with the control group, the difference between the control group and the patients with depression was insignificant. However, the difference between schizophrenia and BAD patients and the control group was significant. According to these results, 87 (49.7\%) of 175 psychiatric patients had Toxoplasma infection before, and $10(5.7 \%)$ patients were still undergoing Toxoplasma infection.

T. gondii, which can lead to fetal destruction and abortus with the transplacental transmission, is reported to be a risk factor in the development of many neuropsychiatric diseases. In many studies, it is known that the tachyzoites entering the host body can spread to all the organs of the body in the acute phase, but prefer the brain, eye and heart muscle. It is thought the immune system activated by the entry of the parasite into the body, consequently release of neurotransmitters and changes in intracellular Ca 2+ may affect the electrical activity of the cell. As a result, changes can be made in the cognitive and psychological state of the host (Ayaz et al, 2016:90-95).

In conclusion, the prevalence of $T$. gondii infection in patients with schizophrenia and bipolar disorder was significantly higher com- pared to the control group. For this reason, T. gondii infection should be considered as a high-risk factor associated with psychiatric disorder. Measurement of anti-Toxoplasma antibodies in psychiatric disorders may help evaluate the disease and timely initiating treatment.

\section{Ethics Approval}

The present study was conducted according to the principles of the Declaration of Helsinki. Approval for this study was granted by the Clinical Research Ethics Committee of Cumhuriyet University with decision no. 2018-06/08, dated 06.26.2018.

\section{Conflict of Interest}

The authors declare no conflict of interest.

\section{REFERENCES}

AIELLO, L., GARDNER, T., KING, G., BLANKENSHIP, G., CAVALLERANO, J., (1998). Ferris 3rd, FL, Klein, R. Diabetic retinopathy. Diabetes Care, 21(1), 143-156

AYAZ, E., TURKOGLU, S.A., ORALLAR, H., (2016). Toxoplasma gondii and Epilepsy. Turkiye Parazitol Derg, 40(2), 90

BERDOY, M., WEBSTER, J.P., MACDONALD, D.W., (2000). Fatal attraction in rats infected with Toxoplasma gondii. Proceedings of the Royal Society of 
International Refereed Academic Journal of Sports, Health and Medical Sciences

January - February - March Issue: 34 Winter Semester Year: 2020

Uluslararası Hakemli Akademik Spor Sağlık ve Tıp Bilimleri Dergisi

Ocak - Şubat - Mart Sayı: 34 Kış Dönemi Yıl: 2020 ID:478 K:117

ISSN Print: 2146-8508 Online 2147-1711

(ISO 18001-OH-0090-13001706 / ISO 14001-EM-0090-13001706 / ISO 9001-QM-0090-13001706 / ISO 10002-CM-0090-13001706) (TRADEMARK)

(2015/04315- 2015-GE-18972)

London. Series B: Biological Sciences, 267(1452), 1591-1594

BOLUK, S., OZYURT, B.C., GIRGINKARDESLER, N., KILIMCIOGLU, A.A., (2012). Evaluation of Serological Results of Patients with Suspected Toxoplasmosis Admitted to the Medical Parasitology Laboratory of Celal Bayar University Hospital between 2006-2010. Turkiye Parazitol Derg, 36, 137-141

CELIK, T., KARTALCI, S., AYTAS, O., AKARSU, G. A., GOZUKARA, H., UNAL, S., (2015). Association between latent toxoplasmosis and clinical course of schizophrenia-continuous course of the disease is characteristic for Toxoplasma gondii-infected patients. Folia Parasitol (Praha), 62, pii: 2015.2015

HAMDANI, N., DABAN-HUARD, C., LAJNEF, M., RICHARD, J.R., DELAVEST, M., GODIN, O., JAMAIN, S., (2013). Relationship between Toxoplasma gondii infection and bipolar disorder in a French sample. Journal of affective disorders, 148(2-3), 444-448

MANDARINO, L.J., (1992). Current hypotheses for the biochemical basis of diabetic retinopathy. Diabetes Care, 15(12), 1892-1901.
MARKOVITZ, A.A., SIMANEK, A.M., YOLKEN, R.H., GALEA, S., KOENEN, K., C., CHEN, S., AIELLO, A.E., (2015). Toxoplasma gondii and anxiety disorders in a community-based sample. Brain, behavior, and immunity, 43, 192197

SHARIF, M., SARV, S., SHOKRI, A., TESHNIZI, S.H., RAHIMI, M., MIZANI, A., DARYANI, A., (2015). Toxoplasma gondii infection among sheep and goats in Iran: a systematic review and metaanalysis. Parasitology research, 114(1), $1-16$.

TORREY, E.F., BARTKO, J.J., LUN, Z.R., YOLKEN, R.H., (2006). Antibodies to Toxoplasma gondii in patients with schizophrenia: a meta-analysis. Schizophrenia bulletin, 33(3), 729-736

TORREY, E.F., YOLKEN, R.H., (2003). Toxoplasma gondii and schizophrenia. Emerging infectious diseases, 9(11), 1375

TORREY, E.F., YOLKEN, R.H., (2017). Schizophrenia and infections: the eyes have it. Schizophrenia bulletin, 43(2), 247-252

WALOCHNIK, J., AUER, H., JOACHIM, A., (2017). Parasitic Infections in $\mathrm{Hu}-$ 
SSTB

www.sstbdergisi.com

International Refereed Academic Journal of Sports, Health and Medical Sciences

January - February - March Issue: 34 Winter Semester Year: 2020

Uluslararası Hakemli Akademik Spor Sağık ve Tıp Bilimleri Dergisi

Ocak - Şubat - Mart Sayı: 34 Kış Dönemi Yıl: 2020 ID:478 K:117

ISSN Print: 2146-8508 Online 2147-1711

(ISO 18001-OH-0090-13001706 / ISO 14001-EM-0090-13001706 / ISO 9001-QM-0090-13001706 / ISO 10002-CM-0090-13001706) (TRADEMARK)

(2015/04315- 2015-GE-18972)

mans and Animals Comparative Medicine

(pp. 177-189): Springer

WiTtiNG, P.A., (1979). Learning capac-

ity and memory of normal andToxoplasma-infected laboratory rats and mice. Zeitschrift für Parasitenkunde, 61(1), 2951

\section{YOLKEN, R., TORREY, E.F., DICKERSON,}

$\boldsymbol{F}$, (2017). Evidence of increased exposure to Toxoplasma gondii in individuals with recent onset psychosis but not with established schizophrenia. PLoS neglected tropical diseases, 11(11), e0006040

ZHANG, Y., TRÄSKMAN-BENDZ, L., JANELIDZE, S., LANGENBERG, P., SALEH, A., CONSTANTINE, N., POSTOLACHE, T.T., (2012). Toxoplasma gondii immunoglobulin $G$ antibodies and nonfatal suicidal self-directed violence. The Journal of clinical psychiatry, 73(8), 1069-1076 